\title{
A Scientometric Study on the Analytical Hierarchy Process with Emphasis on Urban Affairs Management
}

\author{
Peyman DAVARAZAR ${ }^{* 1}$, , Fereydoon LOTFOLLAHI ${ }^{1}$ \\ *Corresponding author \\ 1 Oxford Cert Universal Academy, London, ENGLAND \\ 2 University of Aveiro, Department of Environment and Planning, Aveiro, PORTUGAL \\ E-mail: peyman.davarazar@ua.pt \\ DOI: 10.24193/JSSPSI.2020.6.10
}

https://doi.org/10.24193/JSSPSI.2020.6.10

\begin{abstract}
A B S T RA C T
Analytical hierarchy process (AHP) is among the most widely used multi-criteria decision-making (MCDM) methods that have been employed by researchers in various scientific areas all over the world to find the most appropriate solutions for complex and multivariable problems. Despite the popularity of this method, there is no scientometric study on AHP applications in the literature. To fill this gap, the present study aims to present a scientometric analysis on the use of AHP for various applications, in general, and particularly for making the best decisions when dealing with urban management. Current scientific trends in this area were also identified and presented through an in-depth analysis of the findings regarding contributing countries, journals and authors. In addition, the main keywords introduced to the field and the existing categories were explored and identified. Results demonstrated that out of the 37,000 scientific works (including journal articles, proceedings, books, etc.) published so far on the employment of AHP in various fields, only $7 \%$ contributed to the urban affair management issues, whilst China and Iran hold the highest share. Results also indicated that AHP has been efficiently combined with Geographic Information System (GIS) to address the scientific needs in this area. This paper also provides recommendations for relevant future studies.
\end{abstract}

\section{INTRODUCTION}

Analytic Hierarchy Process (AHP) has been widely used as a well-known Multi-Criteria DecisionMaking (MCDM) approach in a wide range of scientific areas (Ghavami et al., 2020). AHP was initially introduced by Saaty (1980) to provide a systematic approach for making science-based decisions (Falah et al., 2020). An expert panel with sufficient knowledge in a specific field of science and technology is assisted in order to analyse the involving criteria and sub-criteria and prioritize them based on pairwise comparisons (Jahanshahi et al., 2019; Kamali et al., 2017). This method has been widely employed in a number of application such as energy production and consumption (Liu and Lee, 2019; Salvia et al., 2019; Stojčetović et al., 2019), sustainability (Calabrese et al., 2019; Hasheminasab et al., 2018; Hidroel, 2019), water and wastewater treatment ( $\mathrm{Hu}$ et al., 2016; Pelorus and Karahalios, 2017), and urban affairs, which is the subject of this scientometric study. Over the past years, urban conditions have undergone significant changes due to rapid industrialization and urbanization (Chu and Tang, 2005). Hence, urban subsystems are experiencing major challenges in terms of their structure and function (Natale et al., 2015). In this context, enough attention has to be paid to the development of urban infrastructures and the related 
processes initiated to meet the needs of the current generation and to be also able to satisfy the requirements of the future generations. On the other hand, urban development should comply with the sustainable development principles. To this end, AHP has been efficiently used to make suitable decisions for effective urban management activities.

Scientometric studies are generally designed to explore the history and the progress made in a certain area of science and technology (Coccia, 2018). They can also be used to trace the trends in the studied field and identify the existing gaps in order to provide recommendations for further studies (Mingers and Leydesdorff, 2015). This method can also be used to demonstrate the contribution of countries, journals and authors to the knowledge in a specific scientific area (Konur et al., 2018). AHP has been widely employed in urban management affairs such as site selection of urban facilities (Tan et al., 2014), urban waste management (Sener et al., 2010) and urban land use planning (Mosadeghi et al., 2015). However, to our knowledge, there has been no scientometric study on the overall application of analytical hierarchy processes.

\section{METHODOLOGY}

This study is a scientometric analysis on the utilization of analytical hierarchy process for various scientific applications with emphasis on urban management. To this end, the following steps were followed aiming to gather and analyse the data required for the study, as followed in most of the scientometric papers in the literature (Bernabò et al., 2017; Davarazar et al., 2020; Hosseini et al., 2018):

a). Selection of the most appropriate database for the extraction of scientific papers of various types (see 3.2.2). There are several databases that can be used for this purpose, namely Google Scholar, Scopus, Web of Science (WoS), etc. Among the mentioned databases, WoS core collection was selected for this study since it contains all high quality journals, conference proceeding papers, etc. (Jiang et al., 2018; Olawumi and Chan, 2018; Wang et al., 2016).

b). Adoption of a computer-based program to manage and analyse the obtained data. There are a number of programs that can be used for this purpose, such as BibExcel, HistCite, CiteSpace, etc. (Cobo, et al., 2011). In this study, CiteSpace (5.3.R4) software was employed to visualize outputs and illustrate the results achieved (Chen, 2017). It is worthy to mention that WoS core collection outputs are compatible with CiteSpace (Kuo, 2008).

c). Application of a combination of keywords including Ts = ("analytical hierarchy process" or AHP or "analytical network process" or ANP) in the advanced search mode of WoS. TS means that the topic of published studies (title, abstract and keywords) were 98 searched for the mentioned combination of keywords. All of the English published studies were collected based on the appearance of mentioned keywords.

d). Use of a combination of keywords including $\mathrm{Ts}=$ (("analytical hierarchy process" or AHP or "analytical network process" or ANP) and (urban* or city or cities or ${ }^{*}$ town $^{*}$ or ${ }^{*}$ municip $\left.{ }^{*}\right)$ ) in order to extract the works whose topic was the application of analytical hierarchy process for urban management. In this case, Fuzzy string represented as “*” was used to provide wider ranges of words related to applied keywords.

e). Precise screening of the extracted papers to ensure their relevancy.

f). The extracted documents were then saved as "marked list" of WoS.

g). The marked list was then exported from WoS database as "plain text" to be analysed by the CiteSpace (5.3.R4) using the criteria identified for this scientometric analysis.

h). Selection of scientometric criteria including: publication type, publication over years, contributing countries, keywords, authors' affiliation, cited authors, cited journals, categories, and cited documents.

\section{RESULTS AND DISCUSSION}

\subsection{AHP application in various scientific fields}

\subsubsection{Publications over years}

All of the published documents including research results in the literature after the introduction of AHP methodology by Saaty (1980) (Falah et al., 2020) were extracted from WoS using a set of appropriate keywords mentioned in methodology section. The results obtained according to scientometric criteria indicated that a total number of 37,097 papers have been already published on the application of analytical hierarchy method in various scientific areas. Figure 1 presents all the published works over the corresponding years.

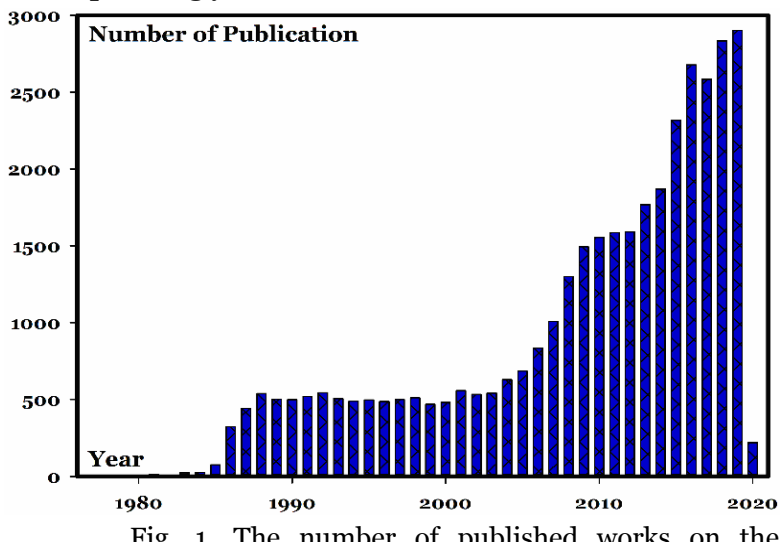

Fig. 1. The number of published works on the application of AHP in various scientific areas. 


\section{A Scientometric Study on the Analytical Hierarchy Process with Emphasis on Urban Affairs Management Journal of Settlements and Spatial Planning, Special Issue, no. 6 (2020) 97-112 \\ Multi-Criteria Spatial Decision Support Systems for Sustainable Development}

As it can be observed in this figure, the number of published works on AHP utilization shows a growth in a very short time span after its introduction to the scientific community.

The annual number of publications also showed a rapid increase after 2005. In addition, the cumulative number of published documents followed a sigmoidal pattern of growth meaning that the increase in the number of publications on the employment of AHP in various analyses has reached a certain point of maturity and after that it usually declines. Such a trend has been previously revealed by scientometric studies related to other scientific areas such as underground carbon dioxide storage (Davarazar et al., 2019) and membrane bioreactors for wastewater treatment (Zandi et al., 2019).
Figure 1 presents the annual and cumulative number of works published in this scientific field.

\subsubsection{Keyword analysis}

CiteSpace was also utilized to extract the main keywords presented in the literature for studies on the use of AHP processes in various scientific areas. As demonstrated in Figure 2 and Table 1, the most widely used keywords in this field are those describing the methodology itself such as "analytical hierarchy process", potential applications, namely "decisionmaking" and the combination of this methodology with other multi-criteria decision making processes, such as Topsis (Choudhary et al., 2012; Pelorus and Karahalios, 2017).

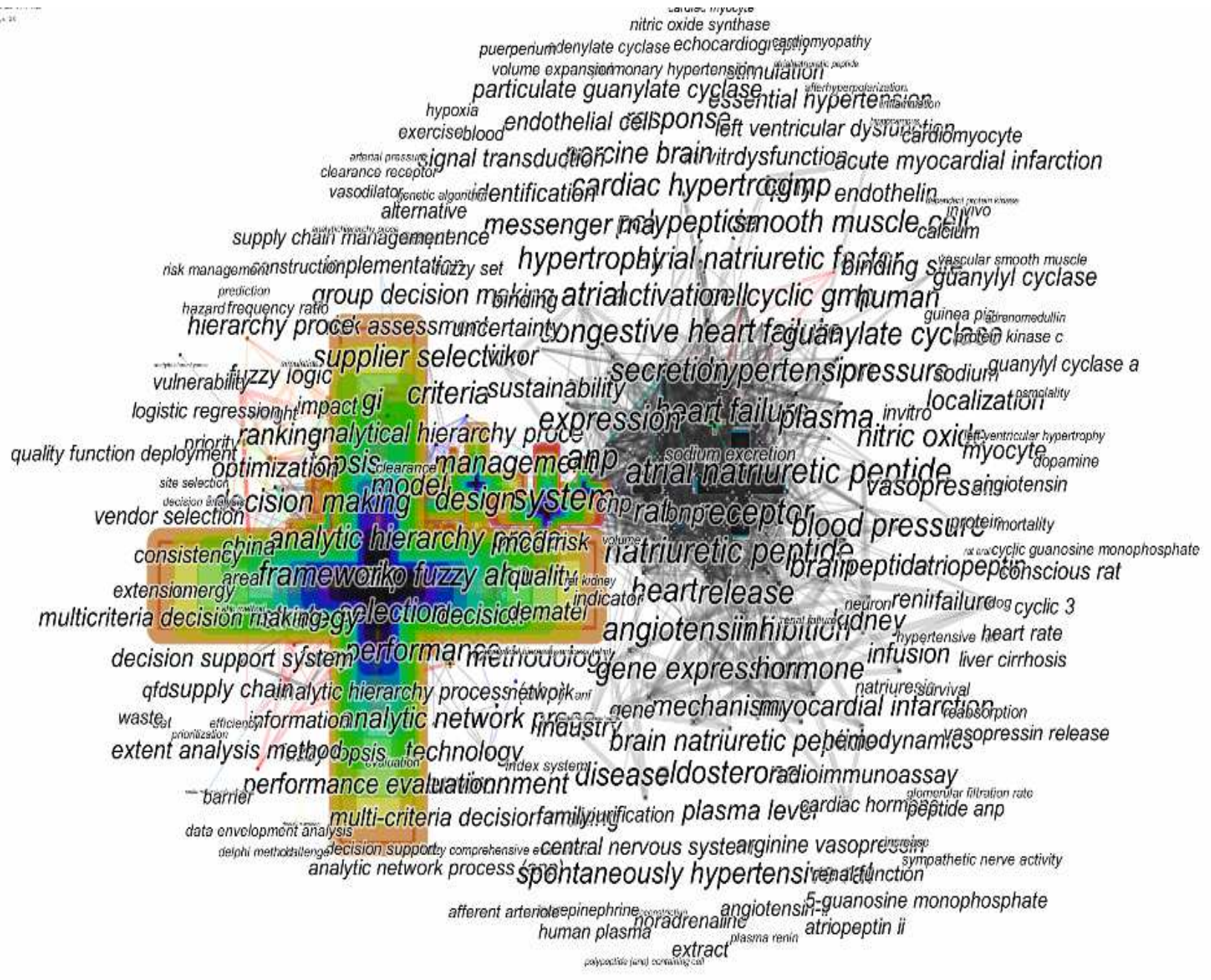

Fig. 2. A schematic representation of co-occurring analysis of the keywords appeared in studies published on the application of AHP in various scientific fields.

The integration of AHP with mathematical logics such as fuzzy principles (Aydi et al., 2016; Cheng et al., 1999; Du et al., 2016; Liu and Lee, 2019) was also identified among most of the resources studied. In addition, keywords analysis can demonstrate that the combination of AHP with data management and analysis such as geographic information system (GIS) for spatial planning purposes (Case et al., 2017; Kamali et al., 2015; Uyan, 2013) has attracted a huge attention among the scientific community. 
Peyman DAVARAZAR, Fereydoon LOTFOLLAHI

Journal of Settlements and Spatial Planning, Special Issue, no. 6 (2020) 97-112

Multi-Criteria Spatial Decision Support Systems for Sustainable Development

Table 1. Output of keywords co-occurring analysis and parameters of scientometric analysis.

\begin{tabular}{l|lrrrr|}
\hline \multicolumn{1}{|c}{ Keyword } & Sigma & Centrality & \multicolumn{1}{c}{ Burst } & Frequency \\
\hline 1 & AHP & 2.68 & 0.05 & 20.22 & 6845 \\
2 & Analytic Hierarchy Process & 1.27 & 0.06 & 4.18 & 3651 \\
3 & Model & 6.25 & 0.03 & 60.52 & 2926 \\
4 & System & 1 & 0.57 & 0 & 2151 \\
5 & Atrial Natriuretic Peptide & $1.24 \mathrm{E}+08$ & 0.04 & 504.64 & 2049 \\
6 & Selection & 5.06 & 0.04 & 43.47 & 1818 \\
7 & Management & 5.53 & 0.03 & 50.99 & 1766 \\
8 & Decision Making & 1.24 & 0.03 & 8.19 & 1557 \\
9 & ANP & 1.15 & 0.3 & 0.52 & 1554 \\
10 & Analytical Hierarchy Process & 1.19 & 0.03 & 6.7 & 1389 \\
11 & Performance & 1.85 & 0.02 & 36.81 & 1196 \\
12 & Fuzzy AHP & 1.16 & 0.01 & 17.17 & 1159 \\
13 & GIS & 90.26 & 0.05 & 99.8 & 1151 \\
14 & Topsis & 3.48 & 0.01 & 84.51 & 1110 \\
15 & Heart Failure & 355.59 & 0.05 & 110.73 & 948 \\
16 & Rat & 9451.23 & 0.03 & 273.02 & 846 \\
17 & Framework & 11.67 & 0.04 & 56.27 & 838 \\
18 & Analytic Hierarchy Process (AHP) & 1.01 & 0 & 8.1 & 782 \\
19 & Expression & 4.96 & 0.02 & 80.06 & 775 \\
20 & Design & 1.2 & 0.03 & 7.26 & 737 \\
21 & Natriuretic Peptide & 1.1 & 0.04 & 2.59 & 692 \\
22 & Receptor & 1824745 & 0.08 & 183.66 & 675 \\
23 & Decision & 1.16 & 0.01 & 14.78 & 674 \\
24 & Criteria & 1.51 & 0.02 & 21.69 & 632 \\
25 & Analytic Network Process & 1.64 & 0.01 & 51.4 & 616 \\
& & & & & \\
\hline
\end{tabular}

These keywords are most widely used to represent scientific papers published so far on the application of AHP in various scientific areas.

\subsubsection{The application of AHP in scientific areas}

In Figure 3 and Table 2 we may note the most visible scientific fields in which analytical hierarchy process has been successfully employed. It is evident from the results achieved that engineering, computer engineering, environmental science and engineering and management are among the main scientific fields in which the application of analytical hierarchy process as a methodical approach holds the highest share.

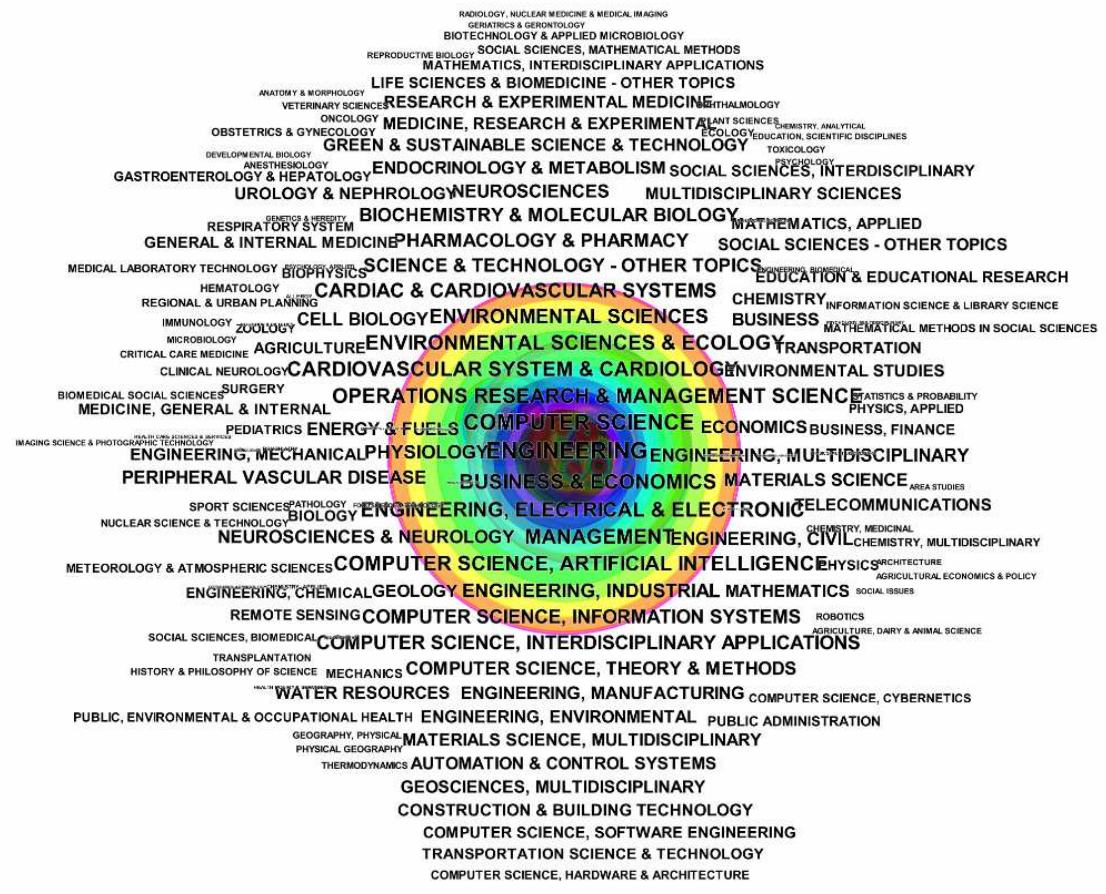

Fig. 3. Contribution of categories in the production of scientific results on the application of AHP in various scientific areas. 
Table 2. Information regarding the categories of published studies obtained from WoS.

\begin{tabular}{l|lrr} 
Rank & \multicolumn{1}{|c}{ Categories } & Burst & Frequency \\
\hline 1 & Engineering & 0.00 & 9478 \\
2 & Computer Science & 50.42 & 6178 \\
3 & Business \& Economics & 37.72 & 3867 \\
4 & Operations Research \& Management Science & 140.92 & 3200 \\
5 & Cardiovascular System \& Cardiology & 642.99 & 2950 \\
6 & Electrical \& Electronic Engineering & 4.26 & 2843 \\
7 & Environmental Sciences \& Ecology & 293.84 & 2817 \\
8 & Management & 34.53 & 2808 \\
9 & Artificial Intelligence Computer Science & 17.86 & 2711 \\
10 & Environmental Sciences & 270.38 & 2340 \\
11 & Cardiac \& Cardiovascular Systems & 401.56 & 2234 \\
12 & Industrial Engineering & 15.73 & 1986 \\
13 & Information Systems Computer Science & 9.36 & 1892 \\
14 & Interdisciplinary Applications Computer Science & 52.42 & 1855 \\
15 & Science \& Technology - Other Topics & 309.43 & 1717 \\
16 & Physiology & 622.93 & 1694 \\
17 & Pharmacology \& Pharmacy & 399.98 & 1672 \\
18 & Biochemistry \& Molecular Biology & 282.19 & 1544 \\
19 & Theory \& Methods Computer Science & 21.00 & 1462 \\
20 & Neurosciences \& Neurology & 361.56 & 1328
\end{tabular}

\subsection{AHP for urban management}

This section has been designed to explore the scientific progress that has been made in the use of AHP for urban management. To this end, some keywords mentioned in the methodology section of this paper were used to extract the relevant publications from WoS, as the most appropriate source database.

\subsubsection{Literature over the years}

By using the mentioned set of keywords, some 2,585 documents were extracted from WoS database. Figure 4 illustrates the annual and cumulative number of studies published in the literature on the application of analytical hierarchy process for urban related issues.

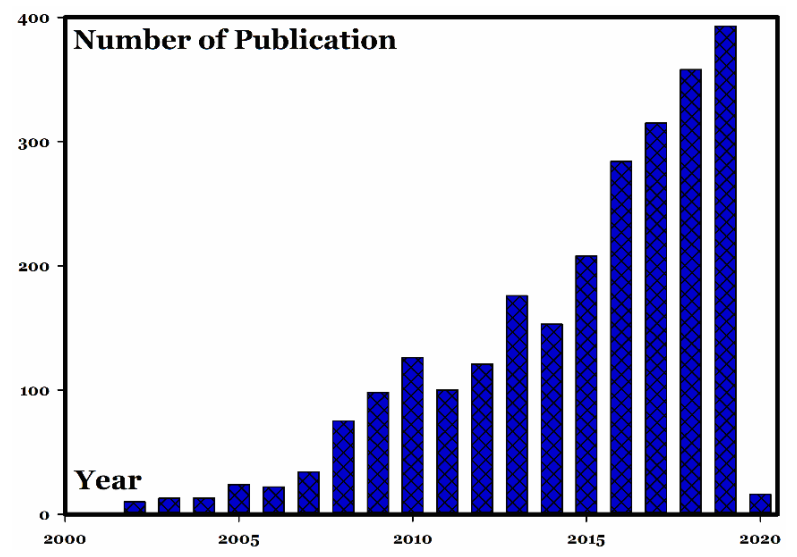

Fig. 4. The number of published studies on the application of AHP in urban management.

As indicated in this figure, research in this field has been initiated since the beginning of 2000 and it has followed an increasing trend over the years. It occurred especially after 2008 and the number of published papers reached about 400 in 2019. We can note that there is an ongoing interest for the application of this methodology to overcome the issues related to urban management and their number is expected to increase over the coming years, following the same trend (Lee and Lim, 2018; Nosal and Solecka, 2014).

\subsubsection{Diversity of published papers}

Figure 5 presents the main types of research works published so far on the application of AHP in urban management.

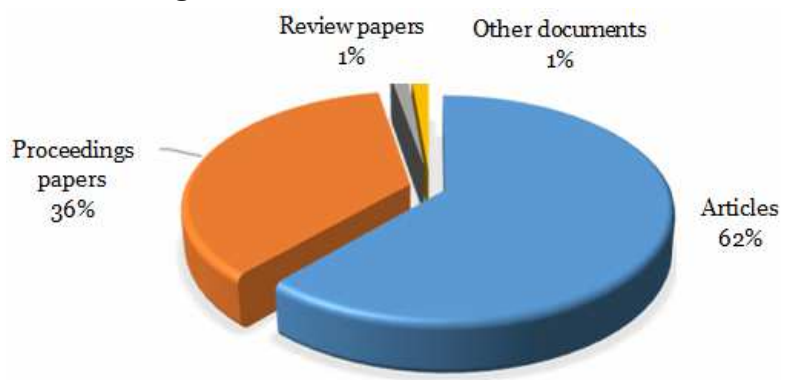

Fig. 5. Types of studies published on the application of AHP in urban management.

As demonstrated in this figure, original research articles, proceedings papers, meeting abstracts, review papers, etc. are the main types that have been published in this regard. Among all these types, basic original research papers hold the highest share (62\%). Proceedings papers are ranked second, with $36 \%$ share, while review papers represent only $1 \%$ of all the related WoS indexed documents. The high 
percentage of proceedings papers on the application of AHP (Davarazar et al., 2019, Davarazar et al., 2020; Jiang et al., 2018; Konur, 2012; Zhao, 2017) can be considered an indicator for the tendency of researchers to share their latest achievements and discuss them in the scientific meetings to enrich their findings. It can be also attributed to the nature of the AHP method, which is based on the necessity of reaching the consensus among experts participating in a given study.

\subsubsection{Contributing countries}

Figure 6 presents the most contributing countries in the production of scientific results based on the use of AHP for the management of urban issues.

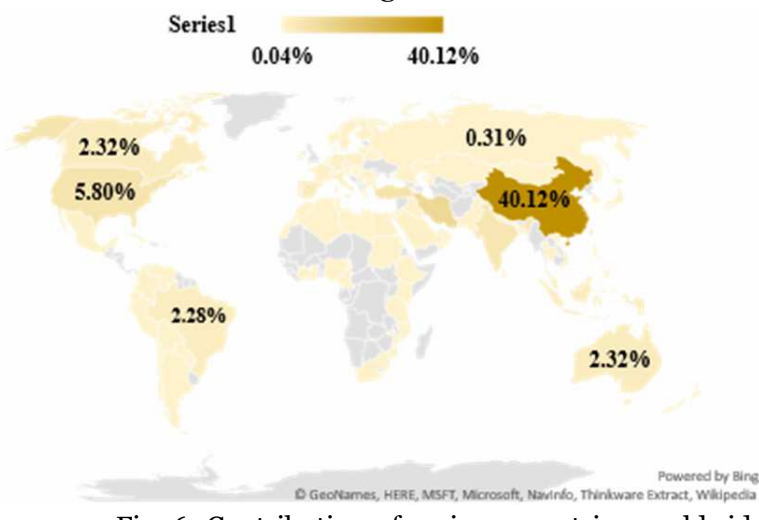

Fig. 6. Contribution of various countries worldwide to the production of scientific papers on the application of AHP in urban management.

Table 3. Contributing countries to the number of published studies on the application of AHP in urban management.

\begin{tabular}{|c|c|c|c|}
\hline Rating & Country & $\begin{array}{c}\text { Count } \\
\text { (no.) }\end{array}$ & $\begin{array}{c}\text { Contribution } \\
(\%)\end{array}$ \\
\hline 1 & China & 1,037 & 40.12 \\
\hline 2 & Iran & 274 & 10.60 \\
\hline 3 & Turkey & 173 & 6.69 \\
\hline 4 & USA & 150 & 5.80 \\
\hline 5 & India & 123 & 4.76 \\
\hline 6 & Taiwan & 95 & 3.68 \\
\hline 7 & Spain & 78 & 3.02 \\
\hline 8 & Italy & 68 & 2.63 \\
\hline 9 & Malaysia & 63 & 2.44 \\
\hline 10 & Australia & 60 & 2.32 \\
\hline 11 & Canada & 60 & 2.32 \\
\hline 12 & Indonesia & 60 & 2.32 \\
\hline 13 & Brazil & 59 & 2.28 \\
\hline 14 & South Korea & 58 & 2.24 \\
\hline 15 & England & 49 & 1.90 \\
\hline 16 & Japan & 43 & 1.66 \\
\hline 17 & Serbia & 37 & 1.43 \\
\hline 18 & Greece & 34 & 1.32 \\
\hline 19 & Lithuania & 33 & 1.28 \\
\hline 20 & Germany & 32 & 1.24 \\
\hline
\end{tabular}

As it can be observed, China is the most contributing country in this regard with more than of $40 \%$ of the published works, seconded by Iran, with about $10 \%$ of all the published articles (Table 3 ).

The high contribution of China was also observed in other scientometric studies (Bernabò et al., 2017; Darko et al., 2019; Gandia et al., 2019; Ouyang et al., 2018). Such high amount of studies can be fundamentally based on some reasons such as the high number of population of this country, as well as the successful development programs designed and implemented in China in recent years such as "special economic zones of the People's Republic of China" (Crane et al., 2018) and the "economic and technological development zones” (Zhao, 2008).

\subsubsection{Keyword analysis}

Figure 7 presents the evolution of keywords related to the application of AHP in studies on urban management. As the figure illustrates, the first keyword that appeared in the literature is the "analytical hierarchy process" in 1996. For a while, no new relevant keyword was highlighted. In 2005, new keywords occurred, namely analytical network process, followed by others related to the management of urban issues such as traffic safety, waste management, fuzzy logic, risk management, which can be classified in clusters including soil loss, transportation measures, technological innovation ability, priority scale, water resource, heavy metal accumulation, etc. Figure 8 also reveals the most frequently keywords used for the application of AHP in urban management. Table 4 presents the related detailed information in this regard. Accordingly, AHP registered the highest frequency, followed by GIS, as the most common complementary tool for the application of analytical hierarchy process.

\subsubsection{Author analysis}

The number of works published by individual authors is considered another scientometric criterion that can demonstrate the scientific contribution of researchers in the field. As it can be observed, Zavadskas E.K., Zhang Y., and Kahraman C. with $0.74 \%, 0.62 \%$ and $0.58 \%$ hold the highest shares in the number of articles published in this field (Table 5).

Despite the number of studies published by individual authors, the citations received by these papers can be considered an even more important scientometric criterion, which can clearly demonstrate the impact of the each individual publication among the scientific community. Figure 9 illustrates authors whose results on the application of analytical hierarchy process for the management of urban affairs were the most cited. Figure 10 illustrates the clusters of the most cited authors. 
A Scientometric Study on the Analytical Hierarchy Process with Emphasis on Urban Affairs Management Journal of Settlements and Spatial Planning, Special Issue, no. 6 (2020) 97-112

Multi-Criteria Spatial Decision Support Systems for Sustainable Development

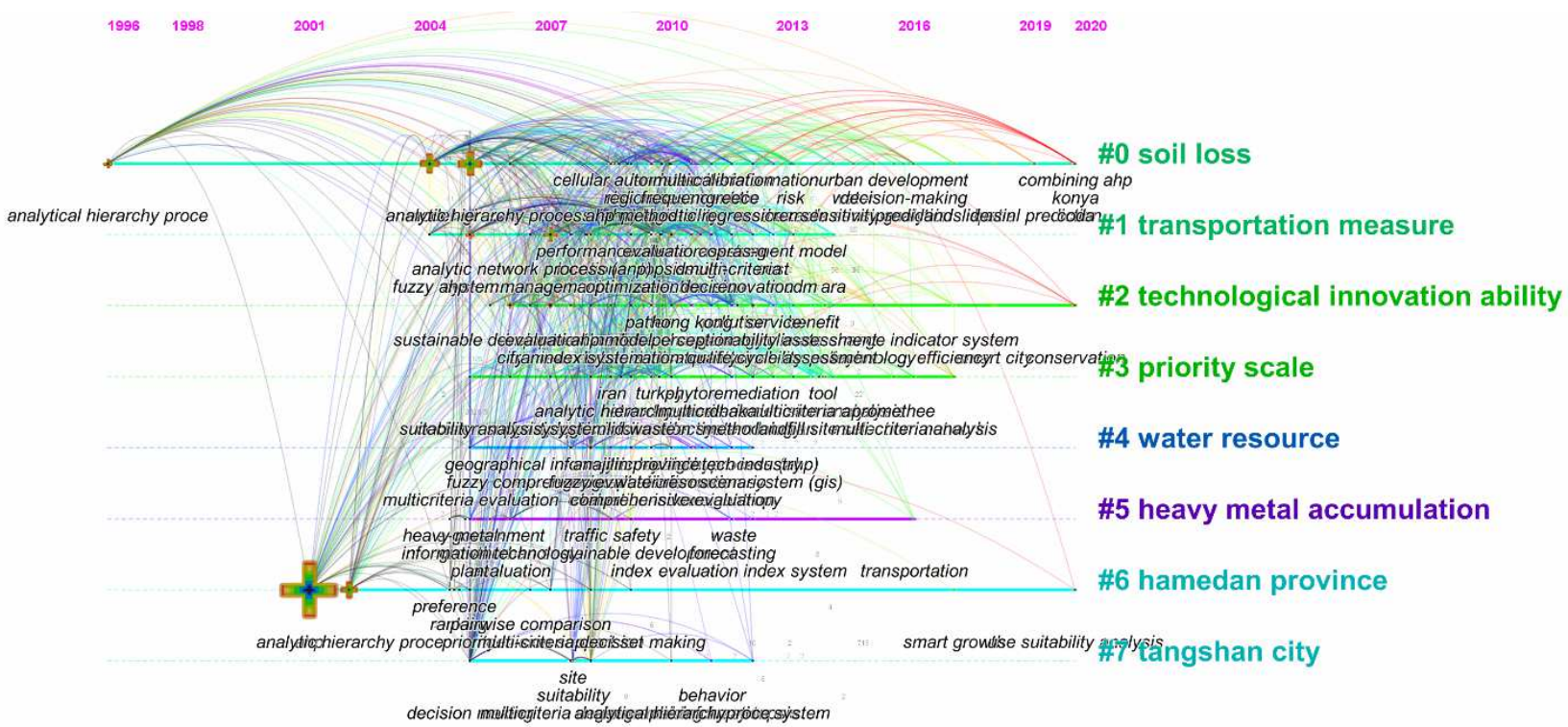

Fig. 7. Appearance of time-line of keywords applied to represent the scientific results published on the application of AHP in urban management.

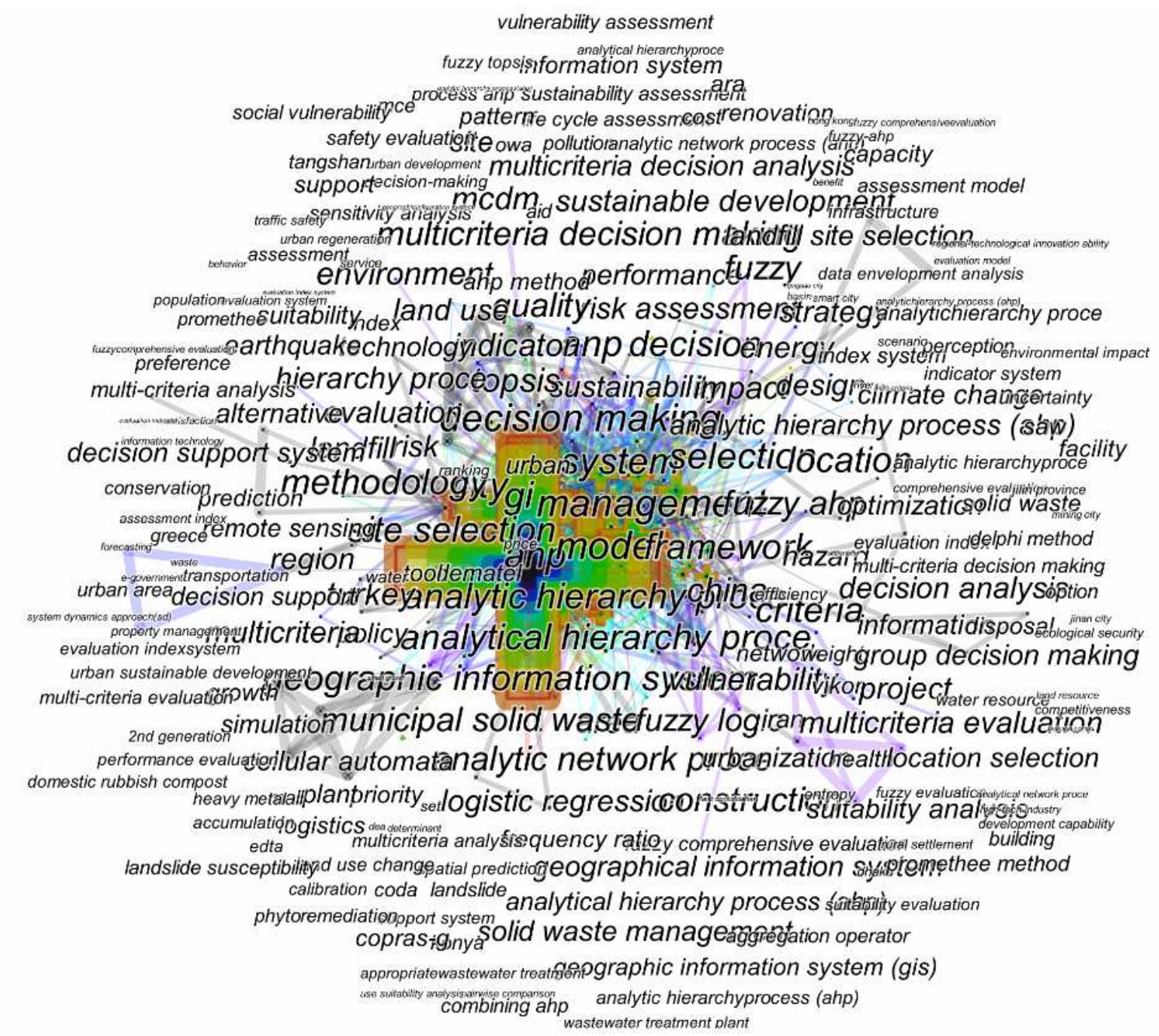

Fig. 8. A schematic representation of co-occurring analysis of the keywords appeared in scientific works published on the application of AHP in urban management. 
Table 4. Output of keywords co-occurring analysis and parameters of scientometric analysis on the application of AHP in urban management.

\begin{tabular}{l|lrrrr} 
Rank & \multicolumn{1}{c}{ Keyword } & Sigma & Centrality & Burst & Frequency \\
\hline 1 & AHP & 3.10 & 0.13 & 9.04 & 719 \\
2 & GIS & 1.10 & 0.11 & 0.87 & 374 \\
3 & Analytic Hierarchy Process & 1.44 & 0.04 & 9.45 & 323 \\
4 & Model & 1.36 & 0.11 & 3.05 & 302 \\
5 & Management & 1.00 & 0.11 & 0.00 & 218 \\
6 & Analytical Hierarchy Process & 1.31 & 0.08 & 3.66 & 200 \\
7 & System & 1.08 & 0.10 & 0.74 & 189 \\
8 & Decision Making & 1.32 & 0.14 & 2.11 & 160 \\
9 & City & 1.05 & 0.08 & 0.62 & 157 \\
10 & Selection & 1.00 & 0.03 & 0.00 & 135 \\
11 & Sustainability & 1.05 & 0.01 & 5.38 & 100 \\
12 & Framework & 1.25 & 0.04 & 5.23 & 91 \\
13 & Fuzzy AHP & 1.04 & 0.05 & 0.73 & 90 \\
14 & China & 1.74 & 0.10 & 5.76 & 84 \\
15 & Site Selection & 1.00 & 0.04 & 0.00 & 81 \\
16 & Geographic Information System & 1.04 & 0.04 & 1.10 & 80 \\
17 & Analytic Hierarchy Process (AHP) & 1.07 & 0.03 & 2.56 & 77 \\
18 & Area & 1.00 & 0.04 & 0.00 & 75 \\
19 & Decision & 1.10 & 0.05 & 1.96 & 73 \\
20 & ANP & 1.06 & 0.07 & 0.86 & 73 \\
21 & Topsis & 1.06 & 0.01 & 4.06 & 73 \\
22 & Impact & 1.02 & 0.02 & 0.84 & 72 \\
23 & Methodology & 1.10 & 0.05 & 1.84 & 68 \\
24 & Municipal Solid Waste & 1.00 & 0.06 & 0.00 & 68 \\
25 & Vulnerability & 1.12 & 0.02 & 5.07 & 66
\end{tabular}

Regarding citation count, the top ranked item is Saaty T. L. (1987) in Cluster \#1, with a citation frequency of 1302. Regarding the citation burst, the top ranked item is Saaty T. L. (1987) in Cluster \#1, with a value of 15.36 . The centrality analysis also demonstrates that Chang N. B. (2008) in Cluster \# 2 is the top ranked item, with a centrality value of 0.22 . Finally, in terms of sigma, Saaty T. L. (1987) in Cluster \#1 with a sigma of 10.02 is on the first position. As it can be observed, Saaty, the developer of AHP methodology, has recorded the most important impact on the scientific community.

Table 5. The list of contributing authors of studies including the application of AHP in urban management.

\begin{tabular}{l|lrr} 
Rating & \multicolumn{1}{|c}{ Author } & $\begin{array}{c}\text { Count } \\
\text { (No.) }\end{array}$ & $\begin{array}{c}\text { Contribution } \\
(\%)\end{array}$ \\
\hline 1 & Zavadskas E.K. & 19 & 0.74 \\
2 & Zhang Y. & 16 & 0.62 \\
3 & Kahraman C. & 15 & 0.58 \\
4 & Pradhan B. & 14 & 0.54 \\
5 & Wang Y. & 14 & 0.54 \\
6 & Chen J. & 12 & 0.46 \\
7 & Li Y. & 12 & 0.46 \\
8 & Liu Y. & 12 & 0.46 \\
9 & Zhang H. & 12 & 0.46 \\
10 & Wang L. & 11 & 0.43
\end{tabular}

\subsubsection{Journals}

Journals are the main sources of studies on the application of analytical hierarchy process for urban affairs management, as well as on other scientific topics. The number of citations that journals have received for the relevant papers can also be considered an important parameter to have an overall image of the contributing parties in this scientific area. In this regard, and as indicated in Figure 12, Eur JORES (1996) in Cluster \# $\mathrm{O}$, with a citation counts of 823 has the most impact on the scientific community among all the contributing journals. In terms of burst, the top ranked item is SUSTAINABILITY-BASEL (2016) in Cluster \#4, with a burst of 22.23. In addition, Fuzzy SETS (2004) in Cluster $\# \mathrm{O}$, with a centrality of 0.13 is the top ranked journal regarding the centrality criterion. Finally, when considering sigma, the top ranked item is Multicriteria D (2005) in Cluster \#2, with a sigma of 5.94. Figure 13 reveals the clusters of journals that have published the scientific results on the application of analytical hierarchy process for the management of urban affairs. Also, Table 6 presents the detailed information (including the frequency, burst, centrality and sigma) of the journals that have published papers on the application of AHP in this scientific area. 


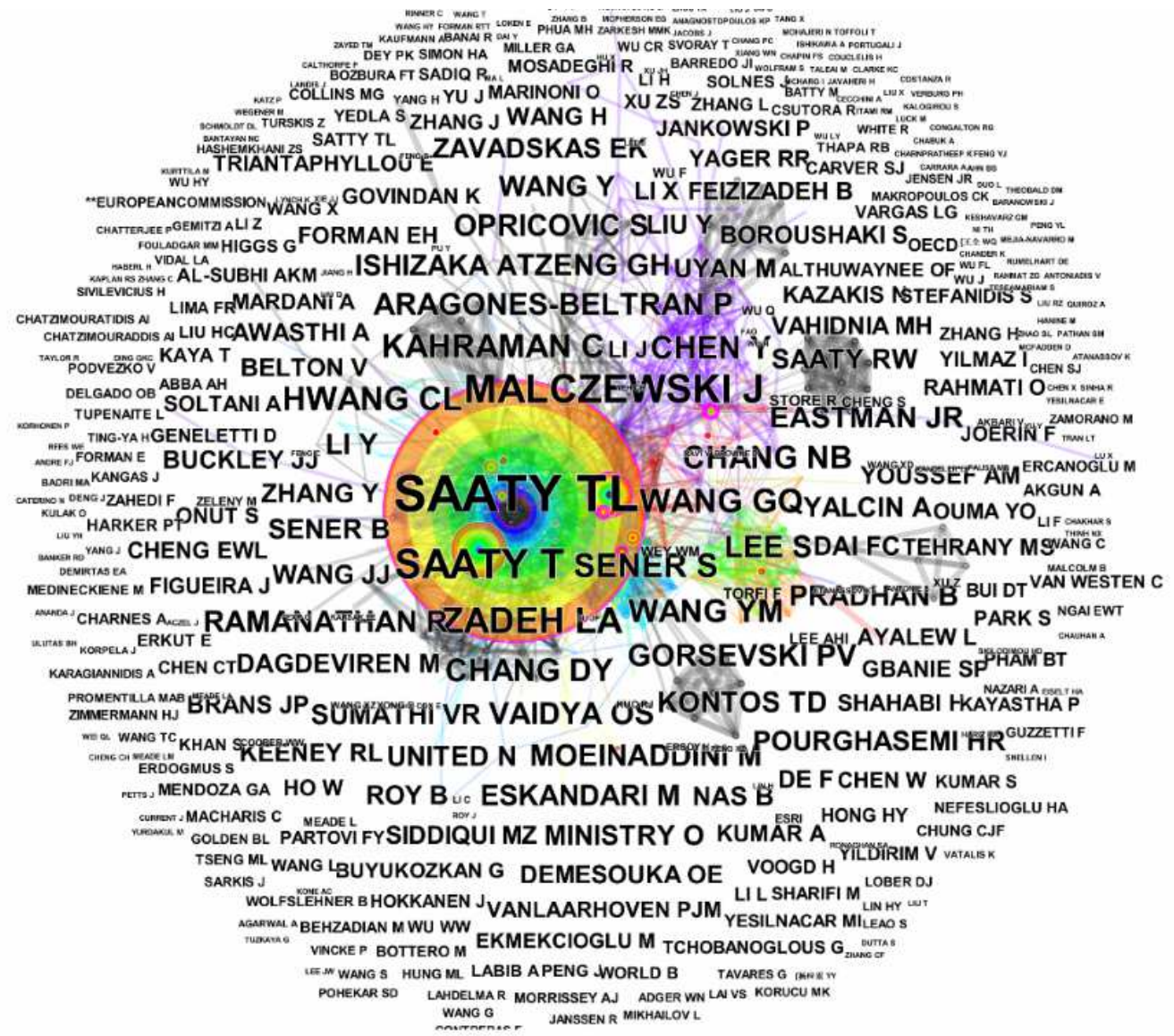

Fig. 9. A schematic illustration demonstrating the most cited authors whose works included the application of AHP in urban management. Graph is with minimized overlaps. The figure containing the exact centrality has been provided in supplementary information.

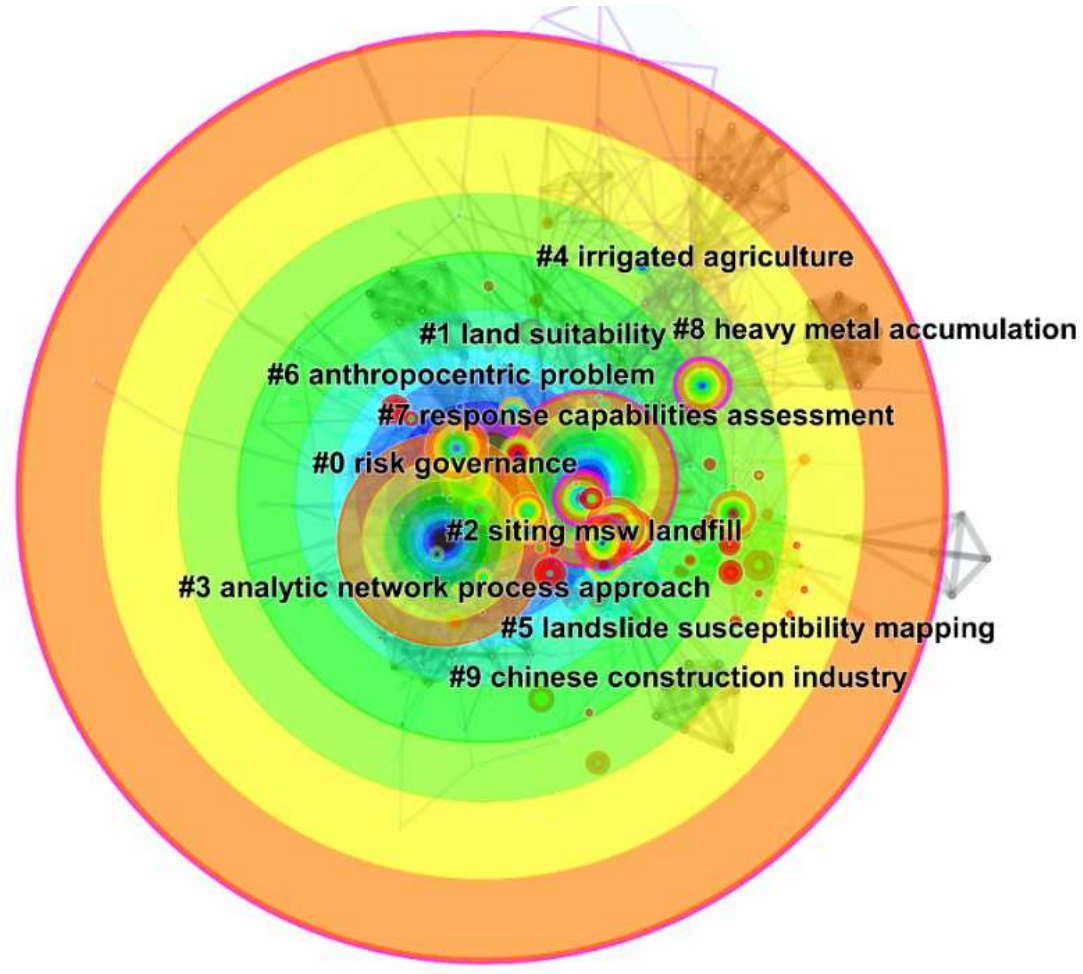

Fig. 10. Clusters of cited authors whose works included the application of AHP in urban management. 
Table 6. Detailed information on the citations received by journals of which articles were collected for the present scientometric study on the application of AHP for urban management affairs and respective parameters of scientometric analysis.

\begin{tabular}{|c|c|c|c|c|c|}
\hline Rating & Journal & Sigma & Centrality & Burst & Frequency \\
\hline 1 & European Journal of Operational Research & 1.03 & 0.06 & 0.62 & 823 \\
\hline 2 & Analytic Hierarchy Process & 4.09 & 0.10 & 14.39 & 757 \\
\hline 3 & Journal of Environmental Management & 1.06 & 0.09 & 0.63 & 545 \\
\hline 4 & Expert Systems with Applications & 1.00 & 0.06 & 0.00 & 462 \\
\hline 5 & Thesis & 1.03 & 0.00 & 17.54 & 339 \\
\hline 6 & Waste management & 1.00 & 0.04 & 0.00 & 291 \\
\hline 7 & Landscape and Urban Planning & 1.03 & 0.05 & 0.59 & 291 \\
\hline 8 & Cleaner Production & 1.19 & 0.01 & 19.56 & 282 \\
\hline 9 & Environmental Earth Sciences & 1.12 & 0.02 & 6.35 & 267 \\
\hline 10 & Science of the Total Environment & 1.35 & 0.02 & 13.71 & 266 \\
\hline 11 & Environmental Monitoring and Assessment & 1.00 & 0.03 & 0.00 & 243 \\
\hline 12 & Renewable \& Sustainable Energy Reviews & 1.00 & 0.03 & 0.00 & 235 \\
\hline 13 & Natural Hazards & 1.02 & 0.01 & 1.81 & 232 \\
\hline 14 & Mathematical Psychology & 1.05 & 0.04 & 1.26 & 230 \\
\hline 15 & $\begin{array}{l}\text { International Journal of Geographical } \\
\text { Information Science }\end{array}$ & 1.01 & 0.02 & 0.94 & 223 \\
\hline 16 & Environmental Modelling \& Software & 1.00 & 0.10 & 0.00 & 222 \\
\hline 17 & Sustainability & 1.14 & 0.01 & 22.23 & 213 \\
\hline 18 & Ecological Indicators & 1.03 & 0.01 & 2.23 & 198 \\
\hline 19 & Environmental Geology & 1.03 & 0.02 & 2.17 & 198 \\
\hline 20 & Land Use Policy & 1.00 & 0.01 & 0.00 & 195 \\
\hline
\end{tabular}

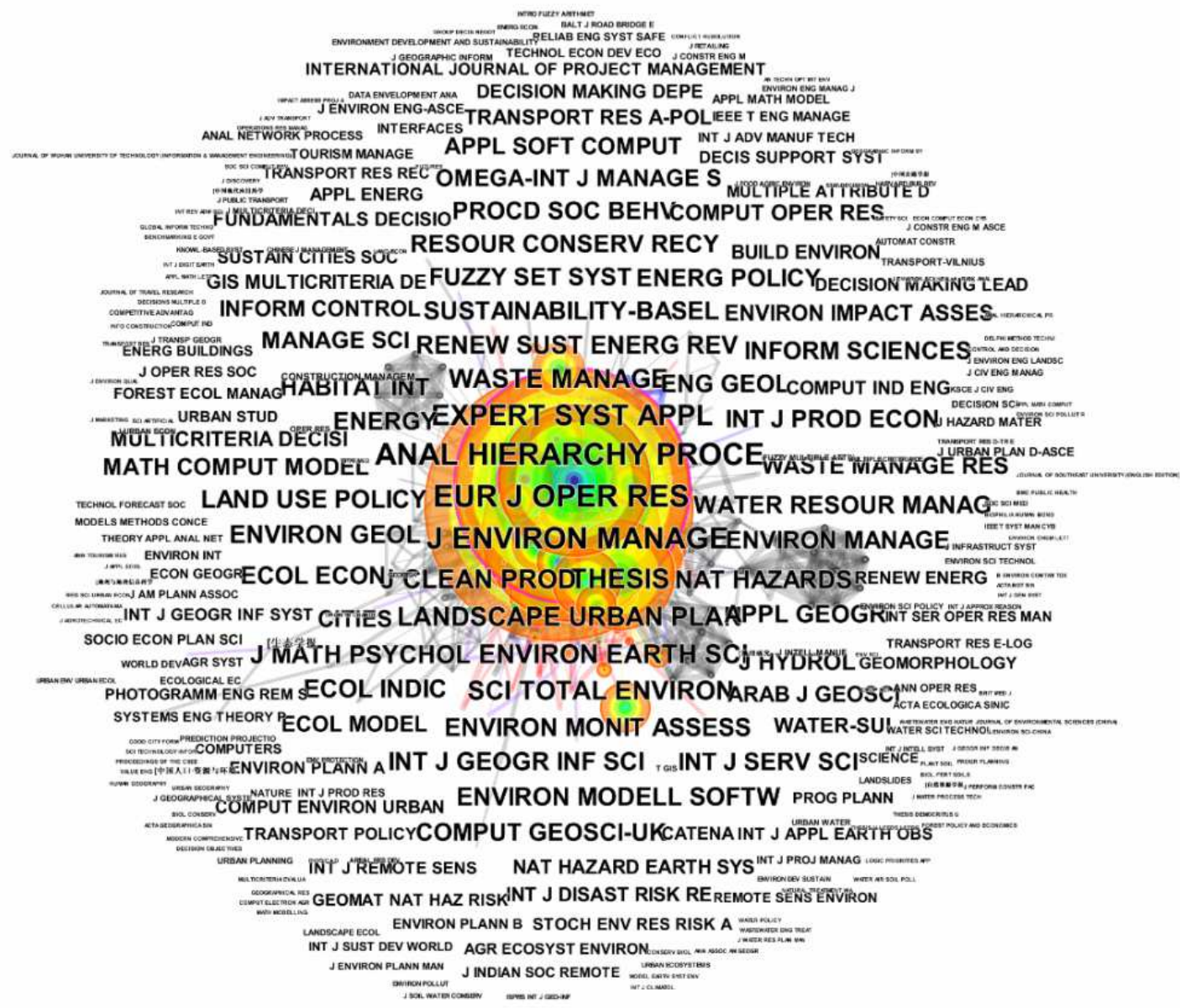

Fig. 12. The cited journals publishing papers on the application of AHP for urban affairs management. This figure is with minimum overlap obtained from CiteSpace. The size of the fonts represent the position of the journal among the cited journals in this scientific field. 
A Scientometric Study on the Analytical Hierarchy Process with Emphasis on Urban Affairs Management Journal of Settlements and Spatial Planning, Special Issue, no. 6 (2020) 97-112

Multi-Criteria Spatial Decision Support Systems for Sustainable Development

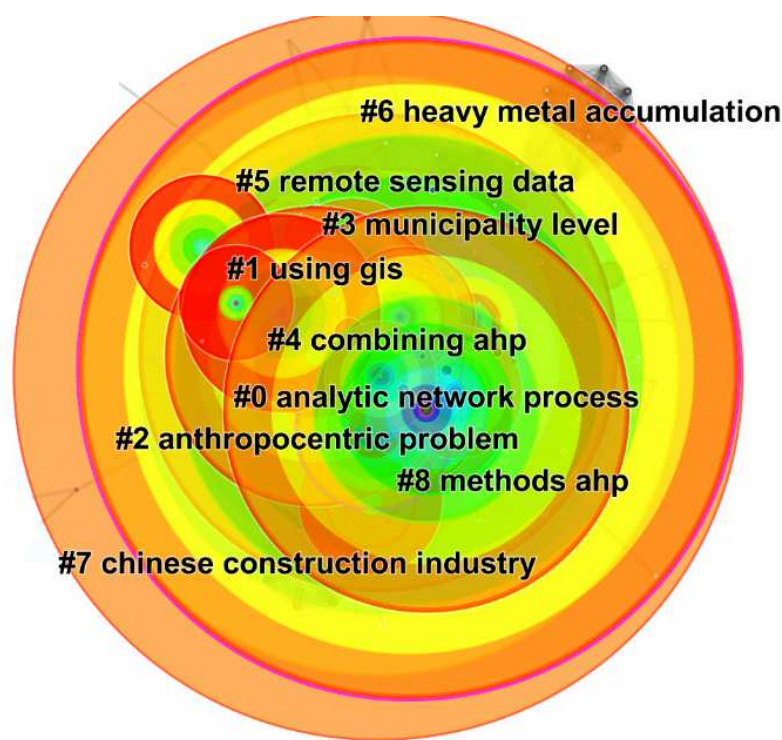

Fig. 13. Clusters of cited journals for the papers they have published on the application of AHP for urban affairs management.

\subsubsection{Categories}

This scientometric indicator can demonstrate the various fields that have received the most focus. As demonstrated in Figure 14, engineering, environmental science and ecology and environmental science are the most important categories in this scientific area. Table 7 also illustrate the categories in this field with the related information including frequencies, bursts, centralities, and sigmas.

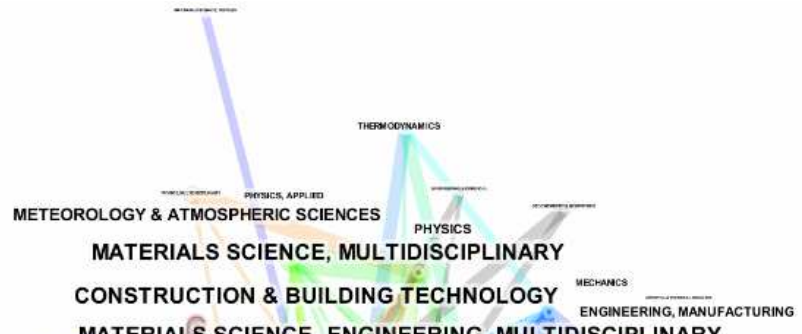

MATERIALS SCIENCE ENGINEERING, MULTIDISCIPLINARY

ENERGY \& FUELS ENGINEERING, MECHANICAL ENGINEERING, CHEMICAL

ENGINEERING, ELECTRICAL \& ELECTRONIC PUBLIC, ENVIRONMENTAL \& OCCUPATIONAL HEALTH

ENGINEERING, ENVIRONMENTAL MATHEMATICS, INTERDISCIPLINARYAPPLICATIONS

BIODNERSTY \& CONSERVATION WATER RESOURCES ENGINEERING AUTOMATION \& CONTROL SYSTEMS

EIODNERSTY \& CONSERVATION WNGINEERING COMPUTER SCIENCE, THEORY \& METHODS
GEOLOGY TELECOMMUNICATIONS

GEOLOGY TELECOMMUNICATIONS
SCIENCE \& TECHNOLOGY - OTHER TOPICS

BIODIVERSITY CONSERVATION ECOLOGY ENVIRONMENTAL SCIENCES OPERATIONS RESEARCH \& MANAGEMENT SCIENCE

GEOSCIENCES, MULTIDISCIPLINARY ENGINEERING, CIVIL TRANSPORTATION MATHEMATICS

ENVIRONMENTAL SCIENCES \& ECOLOGY TRANSPORTATION SCIENCE \& TECHNOLOGY

-2. REMOTE SENSING COMPUTER SCIENCE ENGINEERING, INDUSTRIAL

AGRICULTURE REMOTE SENSING COMPUTER SCIENCE ECONOMICS BUSINESS
ARCHITECTURE URBAN STUDIES

GEOGRAPHY, PHYSICAL ENVIRONMENTAL STUDIES MANAGEMENT COMPUTER SCIENCE, SOFTWARE ENGINEERING

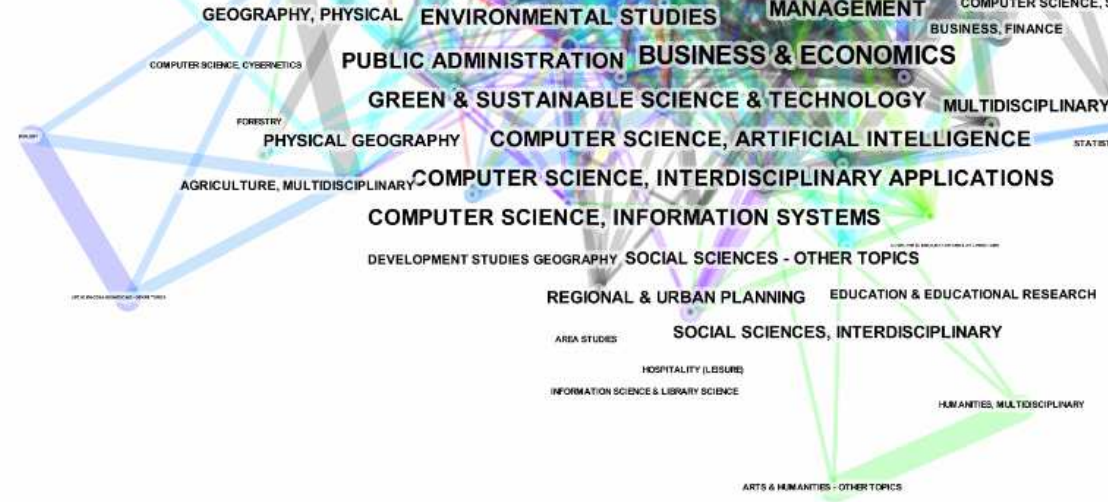

Fig. 14. Contribution of categories in the production of scientific papers on application of AHP for urban affairs management. 
Table 7. Information regarding the categories of published studies on the application of AHP for urban affairs management, obtained from WoS.

\begin{tabular}{l|lrr}
\multicolumn{1}{c}{ Rank } & \multicolumn{1}{c}{ Categories } & Burst & Frequency \\
\hline 1 & Engineering & 0.00 & 815 \\
2 & Environmental Sciences \& Ecology & 6.97 & 745 \\
3 & Environmental Sciences & 11.51 & 619 \\
4 & Computer Science & 22.25 & 341 \\
5 & Science \& Technology - Other Topics & 29.38 & 264 \\
6 & Business \& Economics & 25.73 & 248 \\
7 & Civil Engineering & 7.90 & 226 \\
8 & Water Resources & 0.00 & 218 \\
9 & Environmental Engineering & 1.77 & 210 \\
10 & Geology & 4.76 & 208 \\
11 & Multidisciplinary Geosciences & 4.97 & 206 \\
12 & Environmental Studies & 12.30 & 201 \\
13 & Green \& Sustainable Science \& Technology & 29.12 & 199 \\
14 & Management & 35.65 & 174 \\
15 & Electrical \& Electronic Engineering & 10.90 & 164 \\
16 & Operations Research \& Management Science & 21.99 & 144 \\
17 & Energy \& Fuels & 0.72 & 134 \\
18 & Artificial Intelligence Computer Science & 5.84 & 126 \\
19 & Interdisciplinary Applications Computer Science & 2.10 & 119 \\
20 & Transportation & 4.57 & 119
\end{tabular}

\section{CONCLUSION}

This paper aimed to present a scientometric analysis on the application of Analytical Hierarchy Process in various areas, and especially on the use of this method for urban management affairs. It was observed that only $7 \%$ of all the published documents in this field studied the application of this method for urban management, mainly for the management of environmental issues such as site selection of urban facilities and so on. Although this method has proved its potential to deal a wide range of complex problems, it has not been widely implemented in some countries such as the USA. The integration of AHP with fuzzy logic and effective tools such as geographic information system has also received attention in the literature. The analysis also demonstrated that Saaty, who developed this method, has been the most effective author in the scientific community regarding the scientometric criteria. The category analysis as well as the keywords evolution trend can also clearly indicate that AHP has been used in the analysis of a number of urban affairs despite the fact this method was developed around 35 years ago.

The results of author analysis also demonstrated that the working groups on this scientific field have been well-formed and organized and also the collaboration among the scientific community in this area has been very effective. Such observations can be linked to the types of the published works where authors prefer to present their latest findings in scientific meetings, when compared to other scientific fields. Also, the results of this scientometric analysis can reveal the possibility of the combination of AHP with sustainability principles to make sustainable decisions especially on specific urban areas, for instance providing the clean resources (such as water treatment facilities) as well as management of traffic issues.

\section{REFERENCES}

Aydi A., Abichou T., Nasr I. H., Louati M., Zairi M. (2016), Assessment of land suitability for olive mill wastewater disposal site selection by integrating fuzzy logic, AHP, and WLC in a GIS. Environmental Monitoring and Assessment, 188, 59. DOI: https://doi. org/10.1007/s10661-015-5076-3

Bernabò N., Ciccarelli R., Greco L., Ordinelli A., Mattioli M., Barboni B. (2017), Scientometric study of the effects of exposure to non-ionizing electromagnetic fields on fertility: A contribution to understanding the reasons of partial failure. PLoS ONE, 12(12), 1-17. DOI: https://doi.org/10.1371/journal.pone. 0187890

Calabrese A., Costa R., Levialdi N., Menichini T. (2019), Integrating sustainability into strategic decisionmaking: A fuzzy AHP method for the selection of relevant sustainability issues. Technological Forecasting and Social Change, 139 (November 2018), 155-168. DOI: https://doi.org/10.1016/j.techfore.2018. 11.005

Kamali M. (2020), Guest editorial: an opinion on multi-criteria decision-making analysis for sustainability-based spatial planning practices. Time to improve? Journal of Settlements and Spatial Planning, 
In press, 1-3. DOI: https://doi.org/https://doi.org/ 10.24193/JSSPSI.2020.6.01 K

Chen C. (2014), The CiteSpace manual version 1.01. In College of Computing and Informatics (pp. 1-84).

Cheng C.-H., Yang K.-L., Hwang C.-L. (1999), Evaluating attack helicopters by AHP based on linguistic variable weight. European Journal of Operational Research, 116(2), 423-435. DOI: https://doi.org/10.1016/So377-2217(98)00156-8

Choudhary D., Shankar Ravi, Choudhary D., Shankar R. (2012), An STEEP-fuzzy AHP-TOPSIS framework for evaluation and selection of thermal power plant location: A case study from India. Energy, 42(1), 510-521. DOI: https://doi.org/10.1016/j.energy. 2012.03.010

Chu Y. W., Tang J. T. H. (2005), The internet and civil society: Environmental and labour organizations in Hong Kong. International Journal of Urban and Regional Research, 29(4), 849-866. DOI: https://doi. org/10.1111/j.1468-2427.2005.00625.x

Cobo M. J., López-Herrera A. G., HerreraViedma E., Herrera F. (2011), Science mapping software tools: Review, analysis, and cooperative study among tools. Journal of the American Society for Information Science and Technology, 62(7), 13821402. DOI: https://doi.org/10.1002/asi.21525

Coccia M. (2018), General properties of the evolution of research fields: a scientometric study of human microbiome, evolutionary robotics and astrobiology. Scientometrics, 117, 1265-1283. DOI: https://doi.org/ 10.1007/s11192-018-2902-8

Crane B., Albrecht C. C., Duffin K. M., Albrecht C. C. (2018), China's special economic zones: An analysis of policy to reduce regional disparities. Regional Studies, Regional Science, 5, 98-107. DOI: https://doi.org/10.108o/21681376.2018.1430612

Darko A., Chan A. P. C., Huo X., Owusu-Manu D.-G. (2019), A scientometric analysis and visualization of global green building research. Building and Environment, 149 (November 2018), 501-511. DOI: https://doi.org/10.1016/J.BUILDENV.2018.12.059

Davarazar M., Jahanianfard D., Sheikhnejad Y., Nemati B., Mostafaie A., Zandi S., Khalaj M., Kamali M., Aminabhavi T. M. (2019), Underground carbon dioxide sequestration for climate change mitigation - A scientometric study. Journal of $\mathrm{CO} 2$ Utilization, 33(May), 179-188. DOI: https://doi.org/10. 1016/j.jcou.2019.05.022

Davarazar M., Mostafaie A., Jahanianfard D., Davarazar P., Ghiasi S. A. B., Gorchich M., Nemati B., Kamali M., Aminabhavi T. M. (2020), Treatment technologies for pharmaceutical effluents - A scientometric study. Journal of Environmental Management, 254, 10980o. DOI: https://doi.org/10. 1016/j.jenvman.2019.109800

Du X., Zhou K., Cui Y., Wang J., Zhang N., Sun W. (2016), Application of fuzzy analytical hierarchy process (AHP) and prediction-area (P-A) plot for mineral prospectivity mapping: a case study from the Dananhu metallogenic belt, Xinjiang, NW China. Arabian Journal of Geosciences, 9(4). DOI: https://doi.org/10.1007/s12517-016-2316-y

Falah N., Karimi A., Harandi A. T. (2020), Urban growth modeling using cellular automata model and AHP (case study: Qazvin city). Modeling Earth Systems and Environment, 6(1), 235-248. DOI: https://doi.org/ 10.1007/s40808-019-00674-z

Gandia R. M., Antonialli F., Cavazza B. H., Neto M., Lima D. A. De, Sugano J. Y., Nicolai I., Zambalde A. L. (2019), Autonomous vehicles: scientometric and bibliometric review. Autonomous Vehicles, 39, 9-28. DOI: https://doi.org/10.1080/ 01441647.2018.1518937

Ghavami S. M., Borzooei Z., Maleki J. (2020), An effective approach for assessing risk of failure in urban sewer pipelines using a combination of GIS and AHPDEA. Process Safety and Environmental Protection, 133, 275-285. DOI: https://doi.org/10.1016/j.psep. 2019.10.036

Hasheminasab H., Gholipour Y., Kharrazi M., Streimikiene D. (2018), Life cycle approach in sustainability assessment for petroleum refinery projects with fuzzy-AHP. Energy and Environment, 29(7), 1208-1223. DOI: https://doi.org/10.1177/0958 305X18772425

Hidroel S. (2019), Determination of the Weightings of Hydroelectric Sustainability Criteria by Combining AHP and GP Extended Methods, 24(2) 116-143. DOI: http://dx.doi.org/10.14483/23448393.14469

Hosseini M. R., Martek I., Zavadskas E. K., Aibinu A. A., Arashpour M., Chileshe N. (2018), Critical evaluation of off-site construction research: A Scientometric analysis. Automation in Construction, 87(July 2017), 235-247. DOI: https://doi.org/10.1016/ j.autcon.2017.12.002

Hu W., Liu G., Tu Y. (2016), Wastewater treatment evaluation for enterprises based on fuzzy-AHP comprehensive evaluation: a case study in industrial park in Taihu Basin, China. SpringerPlus, 5(1), 1-15. DOI: https://doi.org/10.1186/s40064-016-2523-8

Jahanshahi A., Kamali M., Khalaj M., Khodaparast Z. (2019), Delphi-based prioritization of economic criteria for development of wave and tidal energy technologies. Energy, 167, 819-827. DOI: https://doi.org/10.1016/j.energy.2018.11.040

Jiang S., Hagesteijn K. F. L., Ni J., Ladewig B. P. (2018), A scientometric study of the research on ion exchange membranes. RSC Advances, 8(42), 2403624048. DOI: https://doi.org/10.1039/c8ra04686g

Kamali M., Alesheikh A. A., Azadeh S., Borazjani A., Jahanshahi A., Khodaparast Z., Khalaj M. (2017), Delphi-AHP and Weighted Index Overlay-GIS Approaches for Industrial Site Selection Case Study: Large Extractive Industrial Units in Iran. 
Journal of Settlements and Spatial Planning, 8(December), 99-105. DOI: https://doi.org/10.24193/ JSSP.2017.2.03

Kamali M., Alesheikh A. A., Khodaparast Z., Hosseinniakani S. M. S., Alavi Borazjani S. A. (2015), Application of Delphi-AHP and Fuzzy-GIS approaches for site selection of large extractive industrial units in Iran. Journal of Settlements and Spatial Planning, 6, 1-7. DOI: https://doi.org/10.24193 /JSSP.2017.2.03

Konur O. (2012), The Evaluation of the Global Research on the Education: A Scientometric Approach. Procedia Social and Behavioral Sciences, 47, 1363-1367. DOI: https://doi.org/10.1016/j.sbspro.2012.06. 827

Kuo J. (2008), Active Learning for Constructing Transliteration. Journal of the American Society for Information Science, 59(1), 126-135. DOI: https://doi.org/10.1002/asi

Lee J. H., Lim S. (2018), An analytic Hierarchy Process (AHP) approach for sustainable assessment of economy-based and community-based urban regeneration: The case of South Korea. Sustainability (Switzerland), 10(12). DOI: https://doi.org/10.3390/ su10124456

Liu S. Y., Lee R. S. (2019), Analysis of the dilemmas of solar energy application for Taiwan building with Fuzzy AHP approach. IOP Conference Series: Earth and Environmental Science, 237(4). DOI: https://doi.org /10.1088/1755-1315/237/4/042006

Mingers J., Leydesdorff L. (2015), A review of theory and practice in scientometrics. European Journal of Operational Research, 246, 1-19. DOI: https://doi.org/10.1016/j.ejor.2015.04.002

Mosadeghi R., Warnken J., Tomlinson R., Mirfenderesk H. (2015), Comparison of Fuzzy-AHP and AHP in a spatial multi-criteria decision making model for urban land-use planning. Computers, Environment and Urban Systems, 49, 54-65. DOI: https://doi.org/10.1016/j.compenvurbsys.2014.10.001 Natale E., Villalba G., Junquera J. E., Zalba S. M. (2015), Assessment of the conservation status of natural and semi-natural patches associated with urban areas through habitat suitability indices. International Journal of Environmental Research, 9(2), 495-504.

Nosal K., Solecka K. (2014), Application of AHP method for multi-criteria evaluation of variants of the integration of Urban public transport. Transportation Research Procedia, 3(July), 269-278. DOI: https://doi. org/10.1016/j.trpro.2014.10.006

Olawumi T. O., Chan D. W. M. (2018), A scientometric review of global research on sustainability and sustainable development. Journal of Cleaner Production, 183, 231-250. DOI: https://doi.org/10. 1016/j.jclepro.2018.02.162

Ouyang W., Wang Y., Lin C., He M., Hao F., Liu H., Zhu W. (2018), Heavy metal loss from agricultural watershed to aquatic system: A scientometrics review. 110
Science of the Total Environment, 637-638, 208-220. DOI: https://doi.org/10.1016/j.scitotenv.2018.04.434

Pelorus Karahalios, H. (2017), The application of the AHP-TOPSIS for evaluating ballast water treatment systems by ship operators. Transportation Research Part D: Transport and Environment, 52, 172-184. DOI: https://doi.org/10.1016/j.trd.2017.03.001

Saaty T. L. (1980), The analytic hierarchy process: planning, priority, setting, resource allocation, McGraw-Hill International Book Co., 287 p.

Salvia A. L., Brandli L. L., Leal Filho W., Locatelli Kalil R. M. (2019), An analysis of the applications of Analytic Hierarchy Process (AHP) for selection of energy efficiency practices in public lighting in a sample of Brazilian cities. Energy Policy, 132(November 2018), 854-864. DOI: https://doi.org/ 10.1016/j.enpol.2019.06.021

Sener S., Sener E., Nas B., Karagüzel R. (2010), Combining AHP with GIS for landfill site selection: a case study in the Lake Beyşehir catchment area (Konya, Turkey). Waste Management (New York, N.Y.), 30(11), 2037-2046. DOI: https://doi.org/10.1016/j.wasman. 2010.05.024

Stojčetović B., Nikolić D., Živković Ž., Bogdanović D. (2019), SWOT-AHP method application to determine current energy situation and define strategies for energy security improvement. Thermal Science, 23(2), 861-872. DOI: https://doi.org/ 10.2298/TSCI180319248S

Tan R. R., Aviso K. B., Huelgas A. P., Promentilla M. A. B. (2014), Fuzzy AHP approach to selection problems in process engineering involving quantitative and qualitative aspects. Process Safety and Environmental Protection, 92(5), 467-475. DOI: https://doi.org/10.1016/j.psep.2013.11.005

Uyan M. (2013), GIS-based solar farms site selection using analytic hierarchy process (AHP) in Karapinar region, Konya/Turkey. Renewable and Sustainable Energy Reviews, 28, 11-17. DOI: https://doi.org/10. 1016/j.rser.2013.07.042

Wang G., Luo L., He Q., Meng X., Xie J., Shi Q. (2016), Mapping the managerial areas of Building Information Modeling (BIM) using scientometric analysis. International Journal of Project Management, 35(4), 670-685. DOI: https://doi.org/10.1016/j.ijpro man.2016.08.001

Zandi S., Nemati B., Jahanianfard D., Davarazar M., Sheikhnejad Y., Mostafaie A., Kamali M., Aminabhavi T. M. (2019), Industrial biowastes treatment using membrane bioreactors (MBRs) -a scientometric study. Journal of Environmental Management, 247, 462-473. DOI: https://doi.org/10.1016/j.jenvman.2019.06.066

Zhao X. (2017), A scientometric review of global BIM research: Analysis and visualization. Automation in Construction, 80, 37-47. DOI: https://doi.org/10.1016 /j.autcon.2017.04.002 
Zhao Y., Shang J. C., Chen C., Wu H. N. (2008), Simulation and evaluation on the eco-industrial system of Changchun economic and technological development zone, China. Environ Monit Assess, 139, 339-349. DOI: https://doi.org/10.1007/s10661-007-9840-x

\section{Supplementary Information}

\section{Scientometric graphs with actual centralities}

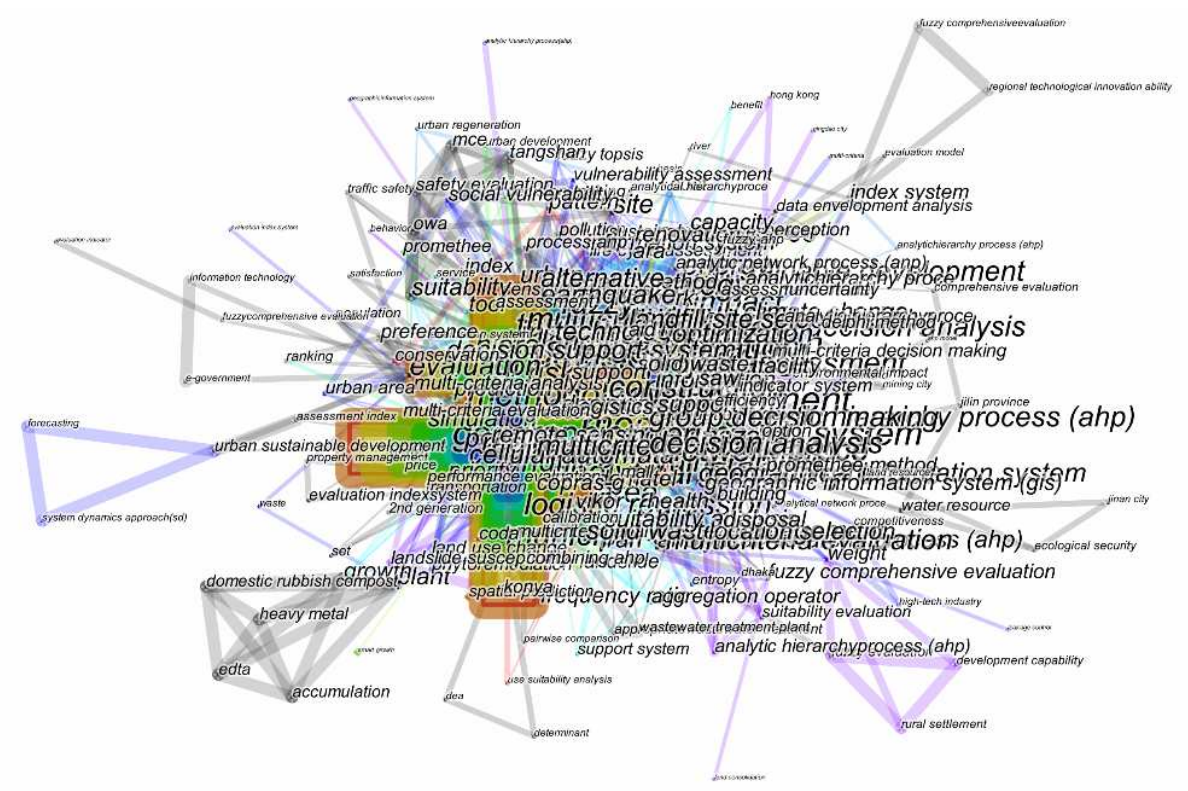

Fig. A.1. A schematic representation of co-occurring analysis of the keywords appeared in the scientific studies published on the application of AHP.

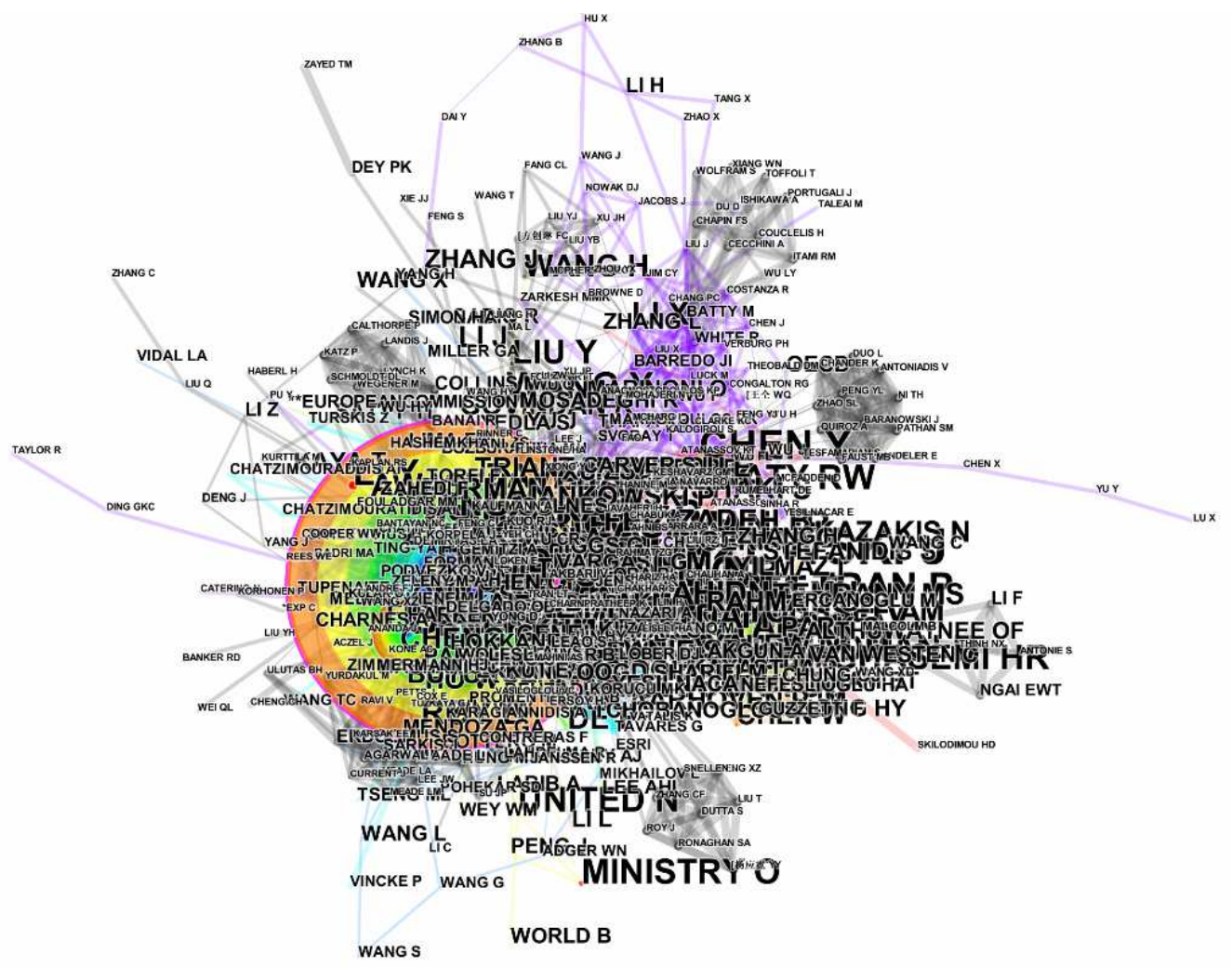

Fig. A.2. A schematic illustration demonstrating the most cited authors. 
Peyman DAVARAZAR, Fereydoon LOTFOLLAHI

Journal of Settlements and Spatial Planning, Special Issue, no. 6 (2020) 97-112

Multi-Criteria Spatial Decision Support Systems for Sustainable Development

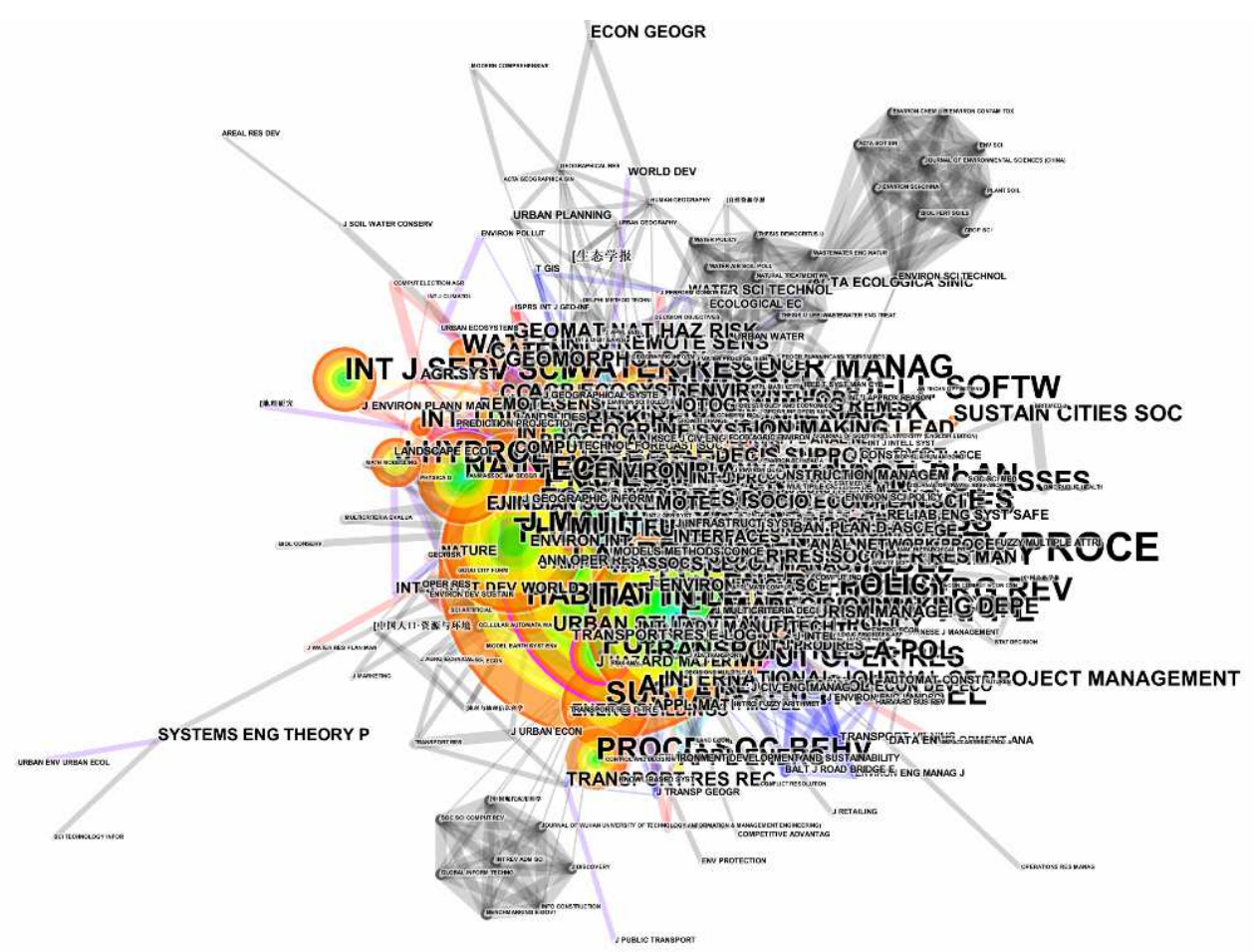

Fig. A.3.The cited journals analysis with minimum overlap obtained from CiteSpace with actual centrality.

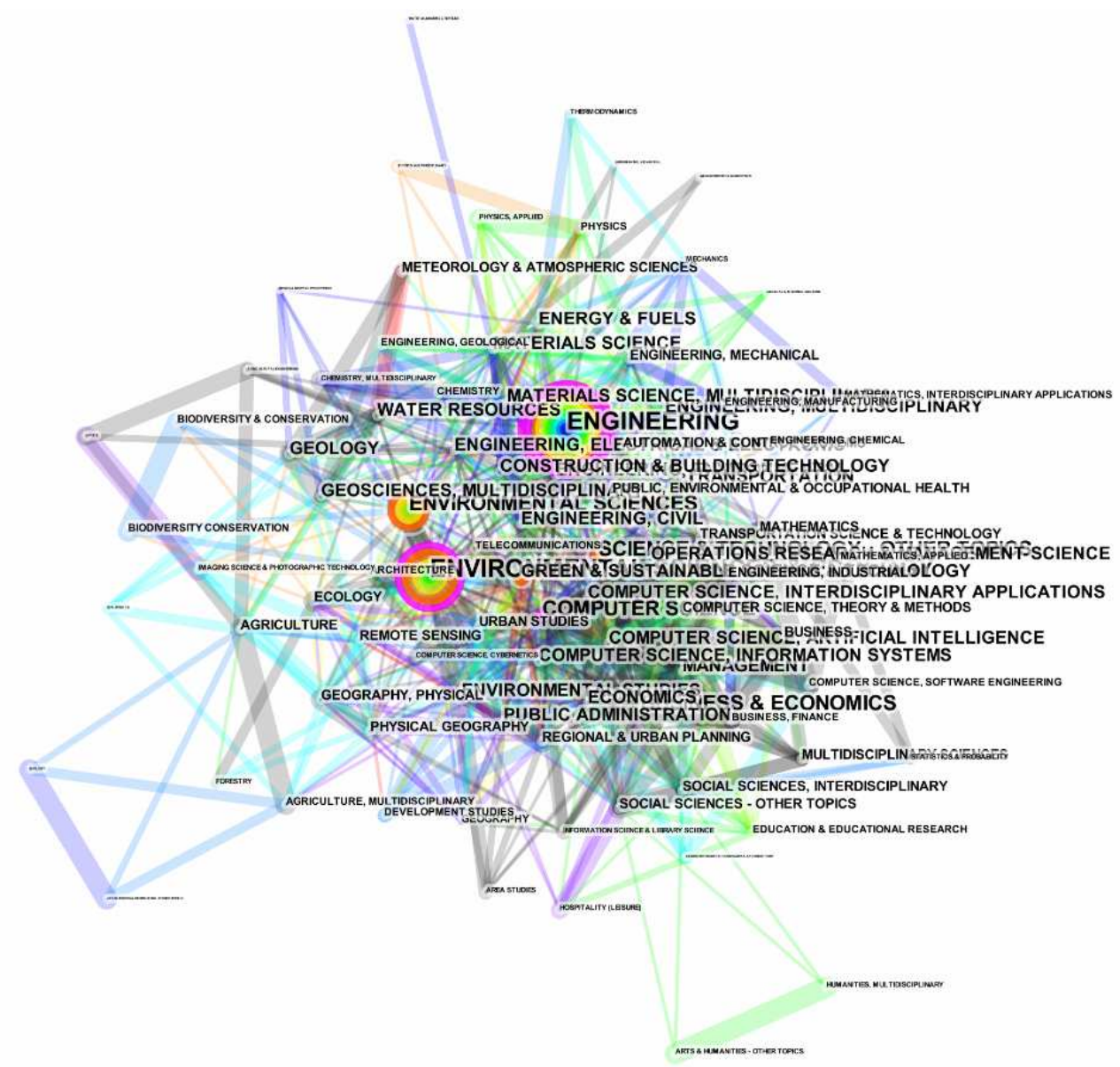

Fig. A.4. A schematic illustration on the categories of scientific papers. 